\title{
CLIMATE CHANGE AND VULNERABILITY OF PADDY CULTIVATION IN NORTH-WEST SELANGOR, MALAYSIA: A SURVEY OF FARMERS' ASSESSMENT
}

\author{
Md. Mahmudul Alam (Postgraduate Student) ${ }^{1}$ \\ rony000@gmail.com \\ Chamhuri Siwar (Emeritus Professor) ${ }^{1}$ \\ csiwar@ukm.my \\ Rafiqul Islam Molla (specialist in Economics) ${ }^{2}$ \\ rimolla@gmail.com \\ Mohd Ekhwan bin Toriman (Associate Professor) ${ }^{1}$ \\ ikhwan@ukm.my \\ Basri Talib (Associate Professor) ${ }^{1}$ \\ basri@ukm.my \\ Universiti Kebangsaan Malaysia $^{1}$ \\ Multimedia University ${ }^{2}$
}

\section{Citation Reference:}

Alam, M.M., Siwar, C., Molla, R.I, Mohd Ekhwan, T., and Talib, B. 2011. Climate Change and Vulnerability of Paddy Cultivation in North-West Selangor, Malaysia: A Survey of Farmers' Assessment, Voice of Academia, Vol. 6(1), pp. 45-56.

This is a pre-publication copy.

The published article is copyrighted by the publisher of the journal. 


\title{
CLIMATE CHANGE AND VULNERABILITY OF PADDY CULTIVATION IN NORTH-WEST SELANGOR, MALAYSIA: A SURVEY OF FARMERS' ASSESSMENT
}

\begin{abstract}
Climate and agriculture highly interrelated. Agriculture is highly dependent on the climatic factors. The climatic factors as well as other factors that are determined by climate cause vulnerability of agriculture and agricultural production. Using a survey method this study aims to determine the impacts of climatic change on agricultural vulnerability in the Integrated Agricultural Development Area (IADA), West Selangor, Malaysia. Results suggest that over the last 5 years vulnerability of the factors like, injurious insects, high temperature, soil fertility loss, and cost of input materials increased greatly due to climatic changes; and the vulnerability of the factors like shortage of rainfall, excessive rainfall, and labor scarcity increased moderately during this period. It is projected that due to climate change agricultural production sustainability will become vulnerable in Malaysia by 2020.
\end{abstract}

Key words: Climate Change; Vulnerability; Agricultural Sustainability; Paddy; Malaysia

\section{INTRODUCTION}

The climatic factors as expressed by the amount of rainfall, sunshine hours, temperature, relative humidity and length of the drought period result in year-to-year and area-to-area variability of crop production. These climatic factors are changing over the time having mixed affects on agriculture. Moreover, the changes in climatic factors are also linked with other environmental changes as well as economic and social changes that affect the agricultural sector of a country. As a result, the change of climatic factors leads to the vulnerability of agriculture.

According to United Nations Development Programme (2005), when in a given range of climatic variations the outcomes - positive or negative - are beyond the coping range and the damages or losses are no longer tolerable for a society (or a system), it is said to be vulnerable.

In a survey, a series of research priorities on climate change were identified by Ierland and Klaassen in 1996. Some of these issues are long term and related to national or international security such as, soil erosion, chemical poisoning or nuclear waste (Daly and Cobb, 1990); some issues are related to daily quality of life such as water pollution, shortage of food or resources (Homer-Dixon 1992). The combined effects of these issues are difficult to predict such as, natural and environmental catastrophes in recent times - floods, landslides, long periods of drought etc (United Nations, 1997). Latter studies examined vulnerability in terms of yield, farm profitability, regional economy, and hunger explicitly considering uncertainty about future climate-change impacts (Reilly 1999; Schimmelpfenning 1996).

Various impacts of climate change affect various sectors, regions and actors in different ways (Klein, Schipper \& Dessai, 2005). Agricultural sector dominates the economies of $25 \%$ of the world's countries, where half of the world's workforce is currently employed. It also accounts for $24 \%$ of world agricultural outputs, and uses $40 \%$ of land area (Food and Agriculture Organization, 2003). Due to the climate change the agricultural sector is vulnerable in terms of productivity. Climate change affect many agriculture relevant factors and climatic factors like rainfall, temperature, weeds, injurious insects, soil fertility, 
drainage water supply, cost of inputs, labor scarcity and paddy prices, etc. These factors vary place to place mostly based on environmental condition. This paper provides a brief outline about the scenario of climate change in Malaysian, and the vulnerability of Malaysian agriculture due to climatic change. It also discusses about the policy options for effectively coping with the vulnerability of climate change.

\section{METHODOLOGY}

There are many climatic factors as well as agriculture relevant other factors that are vulnerable due to climate change. To determine the vulnerability, this study mostly relies on primary data that were collected through a survey on farmers' perception on the impacts of climatic change in the Integrated Agricultural Development Area (IADA), West Selangor, Malaysia. The target group of the survey is paddy producing farmers. A structured questionnaire was used and data were collected through interview guided by the regular remunerators of IADA authority under the direct supervision of IADA officials. IADA in West Selangor consists of eight areas where total recorded paddy farmers are 10.300. A sample of 198 farmers is selected for this study. These 198 households cover 577.53 ha of paddy area. The number of sample is almost proportionately distributed among the eight areas based on the size of the irrigated land area. The sample within the area is selected randomly.

To measure the degree of vulnerability of these factors on paddy cultivation have the perception of paddy producing farmers have been recorded using a 5-point ordinal scale with 1 standing for very high and 5 standing for very low. Data have been analysed using simple statistics of average, ratio, percentages, ANOVA F- statistics, and tables, etc.

\section{Nature and Impacts of Climate Change in Malaysia}

In Malaysia the most challenging issue is the current activities that lead to rapid climate change. According to the United Nations Development Report, carbon dioxide emissions in Malaysia increased by $221 \%$ during the period of 1990 to 2004, and it is included in the list of 30 biggest greenhouse gas emitters (The Associated Press, 2007). Liebman (2007) also mentioned that rapid growth in emissions has been occurred even though Malaysia ratified the Kyoto Protocol and has taken several initiatives to use renewable energy as well as ways to cut emissions. Currently Malaysia ranks as the 26th largest greenhouse gas emitter in the world. It may even move up the list quickly due to the growth rate of emissions.

Here, due to high greenhouse gas emissions the temperature is projected to rise by $0.3^{\circ} \mathrm{C}$ to $4.5^{\circ} \mathrm{C}$. Warmer temperature will cause sea level to rise by about $95 \mathrm{~cm}$ over a hundred year period. The changes in rainfall may fluctuate from about $-30 \%$ to $+30 \%$. This change will reduce crop yield in many areas. Cultivation of some crops such as rubber, oil palm and cocoa will not possible (NRS, 2001). The projection shows maximum monthly precipitation will increase up to $51 \%$ over Pahang, Kelantan and Terengganu, while minimum precipitation will decrease by $32 \%$ to $61 \%$ for all over Peninsular Malaysia. Consequently, annual rainfall will increase up to $10 \%$ in Kelantan, Terengganu, Pahang and North West Coast, and decrease up to 5\% in Selangor and Johor (NAHRIM 2006). This variation of climatic factors will cause the agricultural system vulnerable in Malaysia.

Under current climate change scenario, temperature above $25^{\circ} \mathrm{C}$ may decline grain mass of $4.4 \%$ per $1^{\circ} \mathrm{C}$ rise (Tashiro \& Wardlaw 1989), and grain yield may decline as much 
as by $9.6 \%-10.0 \%$ per $1{ }^{\circ} \mathrm{C}$ rise (Baker $\&$ Allen 1993). Average temperature in rice growing areas in Malaysia is about $26^{\circ} \mathrm{C}$. Singh, Amartalingam, Wan Harun, \& Islam, (1996) mentioned that the actual farm yields of rice in Malaysia vary from 3-5 tons per hectare, where potential yield is 7.2 tons. It also mentioned that there is a decline of rice yield between $4.6 \%-6.1 \%$ per $1{ }^{\circ} \mathrm{C}$ temperature increase under the present $\mathrm{CO}_{2}$ level, but a doubling of $\mathrm{CO}_{2}$ concentration (from present level $340 \mathrm{ppm}$ to 680ppm) may offset the detrimental effect of $4^{\circ} \mathrm{C}$ temperature increase on rice production in Malaysia. In a recent study it has been found that at $1 \%$ increase in temperature will lead to $3.44 \%$ decrease in current paddy yield, and $.03 \%$ decrease in paddy yield in next season. At $1 \%$ increase in rainfall will lead to $.12 \%$ decrease in current paddy yield, and .21\% decrease of paddy yield in next season (Alam, Talib, Siwar \& Toriman, 2010).

Tisdell (1996) mentioned that rainfall variability increases the level of environmental stress that affects the capability of the system to maintain productivity. Alam et al. (2009) mentioned that total yearly rainfall in Malaysia was increasing but its monthly variation was too high. So, the effect of lower rainfall is almost possible to check through proper irrigation system, but the opposite phenomenon of over rainfall for any particular time, especially at the end of the crop cycle or at the maturity period, causes serious and uncontrollable crop damages. As climatic changes cause crop damages, low productivity, high production cost, it leads to income losses to farmers and increase in their poverty level. It causes increases rise in seasonal unemployment rate (Alam \& Siwar 2009; Siwar, Alam, Murad, \& Al-amin, 2009a, 2009b). It is projected that any change in rainfall, either positive or negative, by more than only $0.4 \%$ will cause paddy yield to fall (Table 3 ). Based on the current level of changes of rainfall, this projection shows a very alarming scenario that farmers' income will drop in future (Alam et al. 2010).

\section{Vulnerability of Paddy Cultivation}

One of the factors contributing to the vulnerability of agriculture and agricultural production is the presence of injurious insects in the paddy field. About $43 \%$ of the respondents reported that attacks of injurious insects increased over the last 5 years. However $45 \%$ respondents mentioned there have been no change, and 12\% reported that insect attack in fact decreased. ANOVA $F$ statistics indicates the current and past mean values of the responses differ significantly (at $1 \%$ significant level). Moreover, based on the average value of all responses, the current status of injurious insects is high (average scale value 4.04). It is supported by $72.2 \%$ of the respondents. Five years ago, based on the average value of all responses, the state of injurious insects was normal (average scale value 3.24) which is actually supported by only $24 \%$ of the respondents and $44 \%$ mentioned it was also high. So, the vulnerability of injurious insects is strongly increasing over the time.

Table 1: Changes in the Agricultural Factors over the Last Five Years

\begin{tabular}{lcccc}
\hline \multirow{2}{*}{ Agricultural Factors } & \multicolumn{4}{c}{ No. and \% of Respondent } \\
\cline { 2 - 5 } & Increased & Same & Decreased & ANOVA F-statistic \\
\hline \hline Injurious Insect & $85(42.9 \%)$ & $89(44.9 \%)$ & $24(12.1 \%)$ & $38.85^{\wedge}$ \\
Supply of Drainage Water & $66(33.3 \%)$ & $88(44.4 \%)$ & $44(22.2 \%)$ & 0.13 \\
Shortage of Rainfall & $90(45.5 \%)$ & $81(40.9 \%)$ & $27(13.6 \%)$ & $28.63^{\wedge}$ \\
Excessive Rainfall & $71(35.9 \%)$ & $89(44.9 \%)$ & $38(19.2 \%)$ & $10.62^{\wedge}$ \\
Temperature & $116(58.6 \%)$ & $69(34.8 \%)$ & $13(6.6 \%)$ & $125.57^{\wedge}$
\end{tabular}


Soil Fertility Loss

Labour Scarcity

Paddy Price

Input Cost

Other (Weeds)
$98(49.5 \%) \quad 66(33.3 \%) \quad 34(17.2 \%)$

$45.58^{\wedge}$

$94(47.5 \%) \quad 78(39.4 \%) \quad 26(13.1 \%)$

$40.12^{\wedge}$

$26(13.1 \%) \quad 63(31.8 \%) \quad 109(55.1 \%)$

$121(61.1 \%) \quad 64(32.3 \%) \quad 13(6.6 \%)$

$105.81^{\wedge}$

$147.36^{\wedge}$

$6(17.6 \%) \quad 27(79.4 \%) \quad 1(2.9 \%)$
2.09

Note: \% of total sample is given in parenthesis

\# for this factor, total observations are 38, and total observations for other factors are 198

$\wedge$ denotes significant at $1 \%$ significance level

Table 2: Level of Changes in the Agricultural Factors over the Last Five Years

\begin{tabular}{|c|c|c|c|c|c|c|c|c|c|}
\hline \multirow{2}{*}{$\begin{array}{l}\text { Agricultura } \\
\text { Factors }\end{array}$} & \multirow{2}{*}{ Timeframe } & \multicolumn{4}{|c|}{ Observation Scale* } & \multirow{2}{*}{$\begin{array}{c}\text { Average } \\
\text { Value } \\
\text { of Scale }\end{array}$} & \multirow{2}{*}{ S.D } & \multirow{2}{*}{$\begin{array}{c}\text { Proportion } \\
\text { of "High" } \\
(4 \& 5) \\
\text { Observations }\end{array}$} & \multirow{2}{*}{$\begin{array}{l}\text { Proportion } \\
\text { of "Low" } \\
\text { (1 \& 2) } \\
\text { Observations }\end{array}$} \\
\hline & & 1 & 2 & 3 & 45 & & & & \\
\hline \multirow{2}{*}{$\begin{array}{l}\text { Injurious } \\
\text { Insect }\end{array}$} & Current & 7 & 21 & 27 & 4598 & 4.04 & 1.17 & $72.2 \%$ & $14.1 \%$ \\
\hline & 5 years ago & 28 & 35 & 48 & 3651 & 3.24 & 1.38 & $43.9 \%$ & $31.8 \%$ \\
\hline \multirow{2}{*}{$\begin{array}{l}\text { Supply of } \\
\text { Drainage } \\
\text { Water }\end{array}$} & Current & 46 & 37 & 30 & 5332 & 2.94 & 1.43 & $42.9 \%$ & $41.9 \%$ \\
\hline & 5 years ago & 33 & 56 & 42 & 3433 & 2.89 & 1.34 & $33.8 \%$ & $44.9 \%$ \\
\hline \multirow{2}{*}{$\begin{array}{l}\text { Shortage of } \\
\text { Rainfall }\end{array}$} & Current & 29 & 22 & 51 & 6729 & 3.23 & 1.26 & $48.5 \%$ & $25.8 \%$ \\
\hline & 5 years ago & 45 & 52 & 56 & 3312 & 2.57 & 1.18 & $22.7 \%$ & $49.0 \%$ \\
\hline \multirow{2}{*}{$\begin{array}{l}\text { Excessive } \\
\text { Rainfall } \\
\end{array}$} & Current & 29 & 39 & 74 & 3422 & 2.9 & 1.18 & $28.3 \%$ & $34.3 \%$ \\
\hline & 5 years ago & 34 & 55 & 83 & 197 & 2.55 & 1 & $13.1 \%$ & $44.9 \%$ \\
\hline \multirow{2}{*}{ Temperature } & Current & 11 & 17 & 30 & 7763 & 3.83 & 1.14 & $70.7 \%$ & $14.1 \%$ \\
\hline & 5 years ago & 37 & 70 & 46 & 3510 & 2.55 & 1.13 & $22.7 \%$ & $54.0 \%$ \\
\hline \multirow{2}{*}{$\begin{array}{l}\text { Soil Fertility } \\
\text { Loss }\end{array}$} & Current & 16 & 38 & 27 & 8433 & 3.4 & 1.2 & $59.1 \%$ & $27.3 \%$ \\
\hline & 5 years ago & 39 & 57 & 55 & 3710 & 2.61 & 1.15 & $23.7 \%$ & $48.5 \%$ \\
\hline \multirow{2}{*}{$\begin{array}{l}\text { Labour } \\
\text { Scarcity }\end{array}$} & Current & 22 & 36 & 50 & 6228 & 3.19 & 1.21 & $45.5 \%$ & $29.3 \%$ \\
\hline & 5 years ago & 38 & 63 & 69 & 217 & 2.47 & 1.03 & $14.1 \%$ & $51.0 \%$ \\
\hline \multirow{2}{*}{ Paddy Price } & Current & 75 & 32 & 28 & 3627 & 2.54 & 1.48 & $31.8 \%$ & $54.0 \%$ \\
\hline & 5 years ago & 9 & 22 & 25 & 6280 & 3.92 & 1.18 & $71.7 \%$ & $15.7 \%$ \\
\hline \multirow{2}{*}{ Input Cost } & Current & 5 & 7 & 16 & 8387 & 4.21 & 0.92 & $85.9 \%$ & $6.1 \%$ \\
\hline & 5 years ago & 38 & 59 & 31 & 4327 & 2.81 & 1.34 & $35.4 \%$ & $49.0 \%$ \\
\hline
\end{tabular}

*Scale: 1 = Very Low, 2 = Low, 3 = Normal, 4 = High, 5 = Very High

In respect of supply of drainage in the paddy field, over the last five years, $33.3 \%$ of the respondents said it increased and $44.4 \%$ mentioned no change, and $22.2 \%$ indicated it decreased. Moreover, ANOVA F statistics indicates that the current and past mean values of the responses does not differ significantly. Further, based on the average value of all responses, the current status of lacking in drainage water supply is normal (average scale value 2.94 ) that is actually supported by $15 \%$ respondent, and $43 \%$ said the lacking is still high. Five years ago, based on the average value of all responses, the state of lacking in drainage water supply was normal (average scale value 2.89 ) that is actually supported by only $21 \%$ of the respondents, and $45 \%$ mentioned it was low. So, the drainage water supply performance is increasing over the time means vulnerability decreases. 
In respect of shortage of rainfall over the last five years in paddy field, $45.5 \%$ of the respondents said it increased and $40.9 \%$ mentioned no change, and $13.6 \%$ said it decreased. ANOVA F statistics indicates that the current and past mean values of the responses differ significantly (at $1 \%$ significant level). Moreover, based on the average value of all responses, the current status of low rainfall is normal (average scale value 3.23) that is actually supported by $26 \%$ of the respondents, and $48.5 \%$ said the intensity of low rainfall is high. Five years ago, based on the average value of all responses, the state of low rainfall was normal (average scale value 2.57) that actually supported by only $28 \%$ of the respondents, and $49 \%$ mentioned it was low. So, the vulnerability of low rainfall is moderately increasing over the time.

In case of excessive rainfall over the last five years in paddy field, $36 \%$ of the respondents said it increased and $45 \%$ mentioned no change, and 19\% indicated it decreased. ANOVA $F$ statistics indicates the current and past mean value of the responses differ significantly (at $1 \%$ significant level). Moreover, based on the average value of all responses, the current status of excessive rainfall is normal (average scale value 2.9) that is actually supported by $37.4 \%$ of the respondents, and $28.3 \%$ said the intensity of excessive rainfall is high. Five years ago, based on the average value of all responses, the state of excessive rainfall was normal (average scale value 2.55) that is actually supported by $42 \%$ of the respondents, and $45 \%$ mentioned it was low. So, the vulnerability of excessive rainfall is moderately increasing over the time. But, the projection of paddy yield in Malaysia showed that by 2020 any variation above $0.4 \%$ in rainfall, either positive or negative, will cause decrease in yield of paddy cultivation. This indicates that in Malaysia there is a very high level of vulnerability of paddy productivity in future (Table 3).

Table 3: Projection of Paddy Yield ( $\mathrm{Kg} / \mathrm{Ha})$ with Different Variations of Temperature and Rainfall

\begin{tabular}{|c|c|c|c|c|c|c|c|c|c|c|c|}
\hline \multicolumn{4}{|c|}{ Year 2020} & \multicolumn{4}{|c|}{ Year 2040} & \multicolumn{4}{|c|}{ Year 2060} \\
\hline $\mathrm{CO}_{2}(\mathrm{ppm})$ & 400 & 400 & 400 & $\mathrm{CO}_{2}(\mathrm{ppm})$ & 600 & 600 & 600 & $\mathrm{CO}_{2}(\mathrm{ppm})$ & 800 & 800 & 800 \\
\hline $\left.\mathrm{V}_{\text {temp }}{ }^{\mathrm{o}} \mathrm{C}\right)$ & 0.3 & 0.85 & 1.4 & $\left.V_{\text {temp( }}{ }^{\circ} \mathrm{C}\right)$ & 0.4 & 1.4 & 2.4 & $\left.\mathrm{~V}_{\text {temp }}{ }^{\mathrm{o}} \mathrm{C}\right)$ & 0.6 & 2 & 3.4 \\
\hline $\mathrm{V}_{\text {rainfall }}$ & & & & $\mathrm{V}_{\text {rainfall }}$ & & & & $\mathrm{V}_{\text {rainfall }}$ & & & \\
\hline $14 \%$ & 6,156 & 5,806 & 5,58 & $23 \%$ & 7,342 & 6,942 & 6,54 & $32 \%$ & 8,619 & 8,059 & 7,499 \\
\hline $7 \%$ & 6,646 & 6,306 & 6,08 & $11 \%$ & 8,200 & 7,800 & 7,40 & $15 \%$ & 9,834 & 9,274 & 8,714 \\
\hline $0.40 \%$ & 7,202 & 6,862 & 6,6 & $0.70 \%$ & 9,042 & 8,642 & 8,2 & $1 \%$ & 10,962 & 10,402 & 9,842 \\
\hline $0 \%$ & 7,202 & 6,862 & 6,642 & $0 \%$ & 9,042 & 8,642 & 8,24 & $20 \%$ & 10,962 & 10,402 & 9,642 \\
\hline $0.40 \%$ & 7,202 & 6,862 & 6,642 & $-0.70 \%$ & 9,042 & 8,642 & 8,24 & $-1 \%$ & 10,962 & 10,402 & 9,642 \\
\hline$-7 \%$ & 6,698 & 6,382 & 6,17 & $-11 \%$ & 8,047 & 7,691 & 7,33 & $-15 \%$ & 9,318 & 8,842 & 8,366 \\
\hline$-14 \%$ & 6,194 & 5,901 & 5,712 & $-23 \%$ & 6,962 & 6,654 & 6,34 & $-32 \%$ & 7,454 & 7,073 & 6,693 \\
\hline
\end{tabular}

Source: MOSTE 2001

In case of temperature and high sunshine over the last five years in paddy field, $58.6 \%$ of the respondents said it increased and $34.8 \%$ mentioned no change, and $6.6 \%$ indicated it decreased. ANOVA F statistics indicates the current and past mean value of the responses differ significantly (at 1\% significant level). Moreover, based on the average value of all responses, the current status of high temperature is high (average scale value 3.83) that is actually supported by $70.7 \%$ of the respondents. Five years ago, based on the average value of all responses, the state of high temperature was normal (average scale value 2.55) that is 
actually supported by $23 \%$ of the respondents, and $54 \%$ mentioned it was low. So, the vulnerability of high temperature is strongly increasing over the time.

In case of soil fertility loss over the last five years in paddy field, $49.5 \%$ of the respondents said it increased and 33.3\% mentioned no change, and 17.2\% indicated it decreased. ANOVA F statistics indicates the current and past mean values of the responses differ significantly (at 1\% significant level). Moreover, based on the average value of all responses, the current status of soil fertility loss is normal (average scale value 3.4 ) that is actually supported by $13.6 \%$ of the respondents, and $59.1 \%$ said the intensity of soil fertility loss is high. Five years ago, based on the average value of all responses, the state of soil fertility loss was normal (average scale value 2.61 ) that is actually supported by $27.8 \%$ of the respondents, and $48.5 \%$ mentioned it was low. So, the vulnerability of soil fertility loss is strongly increasing over the time.

In case of labour scarcity over the last five years in paddy production, $47.5 \%$ of the respondents said it increased and 39.4\% mentioned no change, and $13.1 \%$ indicated it decreased. ANOVA F statistics indicates the current and past mean value of the responses differ significantly (at 1\% significant level). Moreover, based on the average value of all responses, the current status of labour scarcity is normal (average scale value 3.19) that is actually supported by $25.3 \%$ of the respondents, and $45.4 \%$ said the intensity of labour scarcity is high. Five years ago, based on the average value of all responses, the state of labour scarcity was low (average scale value 2.47) that is actually supported by $51 \%$ of the respondents, and $34.8 \%$ mentioned it was normal. So, the vulnerability of labour scarcity is moderately increasing over the time.

In case of price of paddy over the last five years, $13.1 \%$ of the respondents said it increased and $31.8 \%$ mentioned no change, and $55.1 \%$ indicated it decreased. ANOVA F statistics indicates the current and past mean value of the responses differ significantly (at $1 \%$ significant level). Moreover, based on the average value of all responses, the current status of low paddy price is normal (average scale value 2.54) that is actually supported by $14.1 \%$ of the respondents, and 54\% said the intensity of low paddy price is low. Five years ago, based on the average value of all responses, the state of low paddy price was high (average scale value 3.92 ) that is actually supported by $71.7 \%$ of the respondents. So, the vulnerability of low paddy price is decreasing over the time.

In case of input cost over the last five years in paddy production, $61.1 \%$ of the respondents said it increased and 32.3\% mentioned no change, and $6.6 \%$ indicated it decreased. ANOVA F statistics indicates the current and past mean values of the responses differ significantly (at 1\% significant level). Moreover, based on the average value of all responses, the current status of increasing rate of input cost is high (average scale value 4.21) that is actually supported by $85.9 \%$ respondent. Five years ago, based on the average value of all responses, the state of input cost was normal (average scale value 2.81) that is actually supported by $15.7 \%$ of the respondents, and $49 \%$ mentioned it was low. So, the vulnerability of input cost is increasing over the time.

In case of other factors like weeds in the crop field, over the last five years in paddy production, $17.6 \%$ of the respondents said it increased and $79.4 \%$ mentioned no change, and $2.9 \%$ indicated it decreased. Moreover, ANOVA F statistics indicates the current and past mean values of the responses does not differ significantly. So, the vulnerability of other factors like weeds is not increasing over the time. 


\section{CONCLUSION AND RECOMMENDATIONS}

The impacts of climate change on agricultural sustainability vary from economic condition of country to country, region to region and time to time. In Malaysia, the climatic change causes change in several agricultural relevant factors that determine the sustainability of agricultural and agricultural production. Analyses of data obtained from the survey suggest that vulnerability of some of the factors like injurious insects (supported by $42.9 \%$ of the farmers), temperature (supports by $58.6 \%$ of the farmers), soil fertility loss (supports by $49.5 \%$ of the farmers), and cost of inputs (supports by $61.1 \%$ of the farmers) highly increased over the last 5 years. For some other factors like shortage of rainfall (supports by $45.5 \%$ of the farmers), excessive rainfall (supports by $35.9 \%$ farmers), and labour scarcity (supports by $47.5 \%$ of the farmers) vulnerability increased moderately. Moreover, the prediction of paddy yield in terms of climate change, in a given level of temperature and $\mathrm{CO}_{2}$ level, shows more than $0.4 \%$ variation of rainfall by 2020 will cause a fall in paddy yield in Malaysia. Therefore the agricultural sustainability in the future in Malaysia is projected to be vulnerable due to climatic changes.

As climate change is a continuous and long term process, its effects and solutions are similarly pains taking and time consuming process. So, adaptation is very essential for long run agricultural sustainability. Adaptation approach should be followed at farm or individual farmer level, and policy level. Technological advancement will play the most crucial role to solve the problem in the long run. Government also needs to use effective subsidy policy and ensure financial sustainability for the farms. In order to ensure sound functioning of the economic, social and environmental system, planned and proactive adaptation strategies are required to be devised and pursued.

\section{REFERENCES}

Alam, M.M. \& Siwar, C. (2009). Socioeconomic impacts and vulnerability of climate change on farming community: A study on Malaysian perspective. Proceedings of the 3rd International Conference on Social Sciences and Humanities. National University of Malaysia, Dec 2-3, Malaysia.

Alam, M.M., Siwar, S. \& Toriman, M.E. (2009). Rainfall variability, water and agricultural sustainability: a socioeconomic study of vulnerability and adaptation of climate change, case of paddy farming in North West Selangor, Malaysia. Presented in the International Conference on Water, Environment, Energy and Society. Agra University, India, Jun 28-30.

Alam, M.M., Talib, B., Siwar, C., Toriman, M.E. (2010). The impacts of climate change on paddy production in Malaysia: Case of paddy farming in North West Selangor. Proceedings of the International Conference of the 4th International MalaysiaThailand Conference on South Asian Studies. National University of Malaysia, Malaysia, Mar 25-26.

Baker, J.T. \& Allen, Jr. L.H. (1993). Contrasting crop species responses to $\mathrm{CO}_{2}$ and temperature: rice, soybean and citrus. Vegetatio, 104/105, 239-260.

Daly, H. \& Cobb, J. (1990). For the common good. Green Print Publishing: London. 
Food and Agriculture Organization. (2003). World agriculture towards 2015/2030: An FAO Perspective. Rome: Food and Agriculture Organisation of the United Nations.

Homer-Dixon, T. (1992). Environment al change and acute conflict. International Security, $16(2), 31-102$.

Ierland, E.C.van \& Klaassen, M. (1996). Socio-economic impacts and climate change. In M. Kok (ed.). Environmental Security and Sustainable Development, 156-172. Global Change Office, RIVM, Bilthoven.

Klein, R.J.T., Schipper, E.L.F. \& Dessai, S. (2005). Integrating mitigation and adaptation into climate and development policy: three research questions. Environmental Science and Policy, 8(6), 579-588.

Liebman, B. (2007). Malaysia leads the world in greenhouse gas emission growth rate. Curb Global Warming. Nov 29 . Retrieved from http://curbglobalwarmingblog.blogspot.com/2007/11/malaysia-leads-world-ingreenhouse-gas.html (Oct 1 2010).

MOSTE. 2001. National Response Strategies to Climate Change. Ministry of Science, Technology and the Environment, Putrajaya, Malaysia.

National Hydraulic Research Institute of Malaysia (NAHRIM) and California Hydrologic Research Laboratory (CHRL). (2006). Final Report: Study of the impact of climate change on the hydrologic regime and water resources of Peninsular Malaysia. Malaysia.

NRS. 2001. National Response Strategies to Climate Change. Ministry of Science, Technology and the Environment, Malaysia.

Reilly, J. (1999). Climate Change: Can Agriculture Adapt?. Choices, 14(1), 4-8.

Schimmelpfenning, D. (1996). Uncertainty in economic models of cimate change impacts. Climatic Change, 33(2), 213-34.

Singh, S., Amartalingam, R., Wan Harun, W.S. \& Islam, M.T. (1996). Simulated impact of climate change on rice production in Peninsular Malaysia. Proceeding of National Conference on Climate Change. pp. 41-49, UPM, Malaysia.

Siwar, C., Alam, M.M., Murad, M.W. \& Al-amin, A.Q. (2009a). Impacts of climate change on agricultural sustainability and poverty in Malaysia. Proceeding of $10^{\text {th }}$ International Business Research Conference. Dubai. UAE. Apr 16-17. Retrieved from http://www.wbiconpro.com/15[1] (Oct 12010 ).

Siwar, C., Alam, M.M., Murad, M.W. \& Al-amin, A.Q. (2009b). A review of the linkages between climate change, agricultural sustainability and poverty in Malaysia. International Review of Business Research Papers, 5(6), 309-321. Retrieved from http://www.bizresearchpapers.com/23.\%20 (Oct 1 2010). 
Tashiro, T. \& Wardlaw, I.F. (1989). A comparison of the effect of high temperature on grain development in wheat and rice. Annals of Botany, 64, 59-65.

The Associated Press. 2007. Malaysian Growth of Carbon Emissions Highest in the World, UN Says. The Irrawaddy. Nov 29. Retrieved from http://www.irrawaddy.org/article.php?art_id=9454 (Oct 1 2010).

Tisdell, C. (1996). Economic indicators to assess the sustainability of conservation farming projects: An evaluation. Agriculture, Ecosystems and Environment 57(2): 117-131.

United Nations Development Programme. (2005). Adaptation policy framework for climate change: Developing policies strategies and measures. B. Lim and E. SpangerSiegfred (eds.). Cambridge University Press: Cambridge, UK.

United Nations. (1997). Critical trends: Global changes and sustainable development. UN Department for Policy Coordination and Sustainable Development, New York. 